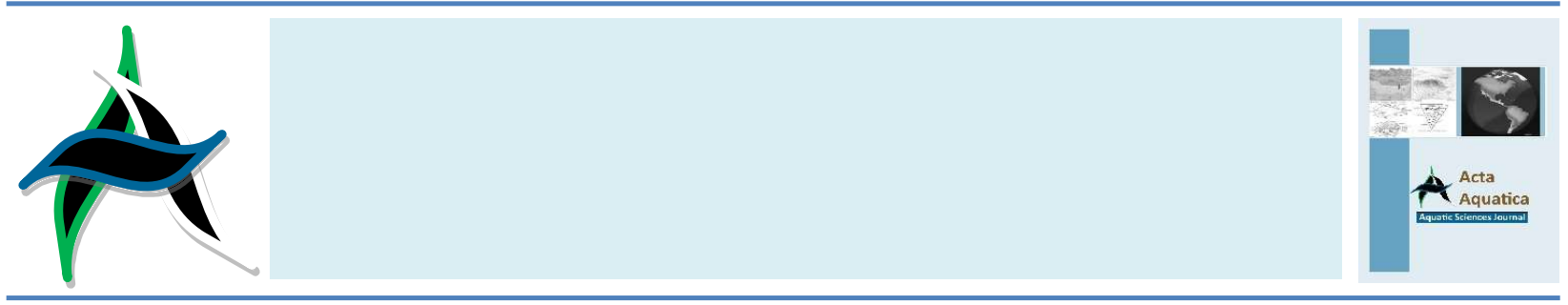

Pengaruh Perbedaan Suhu Terhadap Perkembangan Embrio dan Penetasan Telur Ikan Kakap Putih (Lates calcarifer)

\title{
Effect of Temperature Differences on Embryo Development and Hatching of Sea Bass Eggs (Lates calcarifer)
}

\author{
Mandalica Simanjuntak ${ }^{* 1}$, Rosmaiti $^{2}$, Andika Putriningtias ${ }^{1}$ \\ ${ }^{1}$ Department of Aquaculture, Universitas Samudra, Aceh, Indonesia \\ ${ }^{2}$ Department of Agrotecnology, Universitas Samudra, Aceh, Indonesia
}

\begin{abstract}
Temperature is an environmental factor that can affect the mortality of sea bass in the embryonic phase, because the embryo is the most vulnerable to stress changes because the embryo is still sensitive. The purpose is to determine the optimal temperature and whether the temperature difference can cause significant changes in embryo development, hatching speed, hatching rate and abnormalities in larvae of sea bass. The method used was RAL with 4 treatments and 3 replications, $S 1=26^{\circ} \mathrm{C}, \mathrm{S} 2=28^{\circ} \mathrm{C}, \mathrm{S} 3=30^{\circ} \mathrm{C}$, dan $\mathrm{S} 4=32^{\circ} \mathrm{C}$. $95 \% \mathrm{LSD}$ test showed that embryonic development at $\mathrm{S} 4\left(32^{\circ} \mathrm{C}\right)$ shows the fastest at all stages of embryonic development, the fastest hatching is in $\mathrm{S} 4\left(32^{\circ} \mathrm{C}\right)$ for 656.6 minutes, the highest of hatching in $\mathrm{S} 2\left(28^{\circ} \mathrm{C}\right)$ was $95.258 \%$, the lowest permanent abnormality in $\mathrm{S} 1\left(26^{\circ} \mathrm{C}\right)$ was $0 \%$. The results show that the temperature difference of the incubated media gives a very real effect on the development of the embryo, hatching speed, hatching rate and abnormalities of sea bass larvae (Lates calcarifer).
\end{abstract}

Keywords: egg; embryo; sea bass (Lates calcarifer); temperature.

\section{Abstrak}

Suhu merupakan faktor lingkungan yang dapat berpengaruh terhadap kematian ikan kakap putih pada fase awal kehidupannya yaitu embrio, karena embrio merupakan fase paling rentan terkena stres ketika terjadinya perubahan lingkungan sebab embrio masih sangat sensitif.Tujuan penelitian ini untuk mengetahui suhu optimal serta apakah perbedaan suhu dapat menyebabkan perubahan yang signifikan pada perkembangan embrio, kecepatan penetasan telur, HRserta abnormalitas pada larva ikan Kakap Putih. Metode yang digunakan adalah RAL dengan 4 perlakuan dan 3 ulangan, $\mathrm{S} 1=26^{\circ} \mathrm{C}, \mathrm{S} 2=28^{\circ} \mathrm{C}, \mathrm{S} 3=30^{\circ} \mathrm{C}$, dan $\mathrm{S} 4=32^{\circ} \mathrm{C}$. Hasil dari uji lanjut $\mathrm{BNT} 95 \%$ menunjukkan bahwa perkembangan embio pada perlakuan $\mathrm{S} 4\left(32{ }^{\circ} \mathrm{C}\right)$ menunjukkan perkembangan tercepat pada seluruh tahap perkembangan embrio, penetasan tercepat yaitu pada perlakuan $\mathrm{S} 4\left(32^{\circ} \mathrm{C}\right)$ selama 656,6 menit,derajat penetasan tertinggi pada perlakuan S2 $\left(28^{\circ} \mathrm{C}\right)$ sebesar $95,258 \%$, abnormalitas permanen terendah pada perlakuan S1 $\left(26^{\circ} \mathrm{C}\right)$ sebesar $0 \%$. Hasil dari analisis tersebut menunjukkan bahwa perbedaan suhu memberikan pengaruh yang sangat nyata terhadap perkembangan embrio, kecepatan penetasan telur, derajat penetasan serta abnormalitas larva ikan kakap putih (Lates calcarifer).

Kata Kunci: embrio; ikan Kakap Putih (Lates calcarifer); suhu; telur.

\section{Pendahuluan}

Ikan berkualitas di dapat dari benih berkualitas, benih berkualitas dihasilkan dari telur yang berkualitas. Kualitas telur merupakan faktor utama keberhasilan dalam pembenihan ikan sebab telur kualitas pasti akan memiliki tingkat pembuahan (fertilitas) serta penetasan (hatching rate) yang tinggi. Untuk menghasilkan telur dengan kualitas terbaik didapat dari induk yang berkualitas pula, sementara untuk mendapatkan kuantitas larva yang tinggi harus memperhatikan segala faktor yang dapat mengganggu serta mempengaruhi mulai dari fase awal perkembangannya, salah satunya adalah faktor lingkungan. Menurut Andriyanto et al. (2013), suhu merupakan salah satu faktor lingkungan yang dapat mempengaruhi tingkat kematian ikan Kakap Putih pada fase awal kehidupannya karena embrio masih sangatlah sensitif. Oleh sebab itu diperlukan adanya suatu penelitian untuk menganalisis pengaruh perbedaan suhu terhadap perkembangan embrio dan penetasan telur ikan kakap putih (Lates calcarifer) sehingga memperoleh benih-benih ikan kakap putih yang unggul dan semakin meningkatkan produksi ikan dalam negri.

*Corresponding author: Mandalica Simanjuntak 


\section{Bahan dan Metode}

Penelitian ini dilaksanakan pada 18-23 September 2019 di ruang laboratorium Histologi BPBAP (Balai Perikanan Budidaya Air Payau) Ujung Batee. Alat yang digunakan adalah wadah yang terdiri dari water heater, toples, aerator, kawat, kain, serta alat-alat berupa mikroskop (Olympus pembesaran $4 \times$ ), wadah sementara, seser kain, slide concave, andoer mount adaptor camera. Bahan yang digunakan berupa acriflavine plus, garam ikan kristal $(\mathrm{NaCl})$ serta indukan kakap putih strain Asia (jantan dan betina).

Penelitian ini menggunakan metode eksperimental dengan perlakuan perbedaan suhu (media air) pada telur dengan jumlah telur rata-rata 150 butir telur per wadah. Perlakuan berupa suhu yang digunakan, yaitu: $S_{1}=26^{\circ} \mathrm{C}$ (Kontrol), $\mathrm{S}_{2}=28^{\circ} \mathrm{C}, \mathrm{S}_{3}=30^{\circ} \mathrm{C}, \mathrm{S}_{4}=32^{\circ} \mathrm{C}$. Wadah yang digunakan berupa toples dengan tinggi $24 \mathrm{~cm}$, diameter atas $27,5 \mathrm{~cm}$ dan diameter bawah $23,5 \mathrm{~cm}$, tahapan yang dilakukan mulai dari persiapan wadah dimana media (air) diaerasi selama 2 hari dan suhu diatur dengan water heater. Telur yang dimasukkan ke wadah merupakan hasil dari pemijahan alami indukan kakap putih strain Asia di BPBAP UB yang diambil secara manual dengan seser tanpa menggunakan eggcollector.Variabel yang diamati yaitu perkembangan embrio dari tahap ke tahap, daya tetas telur (Hatching Rate), waktu tetas telur (Hatching Time), suhu optimum penetasan serta abnormalitas telur.

Parameter daya tetas telur (Hatching Rate), dihitung dengan menggunakan persamaan Effendie (1979) dalam Aidil et al. (2016)sebagai berikut:

$\mathrm{HR}=\frac{\Sigma J T M(\text { Jumlah telur yang menetas })}{\Sigma J T B(\text { Jumlah total telur yang diamati })} \times 100$

Waktu penetasan telur (Hatching Time) menggunakan persamaan:

$$
\mathrm{HT}=\mathrm{H}_{\mathrm{t}}-\mathrm{H}_{0}
$$

Abnormalitas telur menurut Wirawan 2005 dalamWahyuningtias (2015):

$$
\text { Abnormal }=\frac{\text { Jumlah Larva Abnormal }}{\text { Jumlah Larva Normal }} \times 100 \%
$$

Telur mulai diamati setelah dimasukkan ke dalam wadah pada masing-masing perlakuan, pengamatan perkembangan telur dilakukan di bawah mikroskop hingga seluruh telur menetas.

Analisis stastistik yang digunakan ANOVA satu arah dengan uji lanjut BNT pada tingkat kepercayaan 95\%.

\section{Hasil dan Bahasan}

\subsection{Perkembangan Embrio Serta Penetasan Telur Kakap Putih}

Hasil uji sidik ragam (ANOVA) menunjukkan bahwa suhu berpengaruh sangat nyata terhadap perkembangan embrio. Hal ini terlihat dari perkembangan embrio lebih cepat pada perlakuan suhu yang lebih tinggi. Sedangkan pada perlakuan suhu yang lebih rendah perkembangan embrio berjalan secara lambat.

\begin{tabular}{|c|c|c|c|c|}
\hline \multicolumn{2}{|c|}{$\begin{array}{l}\text { Perkembangan } \\
\text { Telur (menit) }\end{array}$} & Embrio dan & Penetasa & \multirow{2}{*}{$\begin{array}{l}\text { Perlakuan } \\
\text { (Suhu) } \\
\text { Vase } \\
\text { Perkembangan }\end{array}$} \\
\hline $\begin{array}{l}\text { S1 } \\
\left(26^{\circ} \mathrm{C}\right)\end{array}$ & $\begin{array}{l}\text { S2 } \\
\left(28^{\circ} \mathrm{C}\right)\end{array}$ & $\begin{array}{l}\text { S3 } \\
\left(30^{\circ} \mathrm{C}\right)\end{array}$ & $\begin{array}{l}\text { S4 } \\
\left(32^{\circ} \mathrm{C}\right)\end{array}$ & \\
\hline $72,5^{c}$ & $68^{\mathrm{bc}}$ & $66^{\mathrm{ab}}$ & $63^{a}$ & Morula \\
\hline $98,5^{c}$ & $93^{b}$ & $87,5^{a}$ & $83,5^{a}$ & Blastula \\
\hline $322^{d}$ & $272,5^{c}$ & $249^{b}$ & $235^{a}$ & Gastrula \\
\hline $606,5^{d}$ & $414^{c}$ & $354^{b}$ & $287^{a}$ & Organogenesis \\
\hline $2040^{d}$ & $837,5^{c}$ & $826^{b}$ & $656,5^{a}$ & Penetasan \\
\hline
\end{tabular}

Tabel 1. Perkembangan Embrio dan Penetasan Telur

\subsubsection{Morula}

Berdasarkan hasil uji lanjut Beda Nyata Terkecil (BNT) dengan tingkat kepercayaan $95 \%$ pada kecepatan embrio memasuki fase morula (Tabel 4), embrio pada perlakuan S4 merupakan embrio tercepat yang memasuki fase morula yaitu 63 menit, diikuti dengan perlakuan S3 yaitu 66 menit, perlakuan S2 dengan 68 menit dan S1 yaitu 72,5 menit dimana perlakuan S4 berbeda dari perlakuan S1, S2, dan S3. Kecepatan perkembangan embrio memasuki fase morula pada perlakuan S4 diduga akibat suhu media yang lebih tinggi dibandingkan pada perlakuan lainnya. Hal ini sesuai dengan pernyataan Farida et al. (2016) yaitu suhu yang lebih tinggi akan menyebabkan perkembangan embrio pada fase morula akan lebih cepat pula, sedangkan suhu yang lebih rendah akan memperlambat perkembangan embrio memasuki fase morula. Pada penelitian yang dilaporkan oleh Thépot (2015) terlihat bahwa embrio kakap putih memasuki fase Morula pada waktu 1 jam 9 menit, hal ini menunjukkan bahwa hasil penelitian yang didapat tidak berbeda jauh dengan hasil tersebut.

\subsubsection{Blastula}

Berdasarkan hasil uji lanjut Beda Nyata Terkecil (BNT) dengan tingkat kepercayaan 95\% pada kecepatan embrio memasuki fase blastula (Tabel 5), embrio pada perlakuan S4 merupakan embrio tercepat yang memasuki fase blastula yaitu 83,5 menitlalu diikuti oleh perlakuan S3 yaitu 87,5 menit, S2 yaitu 93 menit dan yang paling lambat adalah perlakuan S1 yaitu 98,5 menit. Dari tabel 5 dapat dilihat bahwa perlakuan S4 berbeda nyata dengan S1 dan S2, namun tidak berbeda nyata terhadap perlakuan S3. Hal ini sesuai dengan pernyataan Redha et al. (2014)bahwa suhu berpengaruh nyata terhadap kecepatan perkembangan embrio pada fase blastula yaitu pada suhu yang lebih tinggi menyebabkan perkembangan embrio lebih cepat dibandingkan suhu yang lebih rendah. Pada penelitian yang dilaporkan oleh Thépot (2015) terlihat bahwa embrio kakap putih memasuki fase Blastula pada 1 jam 20 menit, hal ini menunjukkan bahwa hasil penelitian yang didapat tidak terlalu berbeda dengan hasil tersebut walau mengalami ketertinggalan beberapa menit, menunjukkan bahwa perkembangan embrio pada fase blastula masih dianggap normal.

\subsubsection{Gastrula}

Berdasarkan hasil uji lanjut Beda Nyata Terkecil (BNT) dengan taraf kepercayaan $95 \%$ fase gastrula dapat dilihat dari 
keempat perlakuan tersebut, S4 (235 menit) merupakan perlakuan tercepat yang memasuki fase gastrula, lalu perlakuan S3 (249 menit), S2 (272,5 menit) dan yang paling lambat adalah perlakuan S1 (322 menit). Terlihat dari perbedaan rentang waktu rata-rata perkembangan embrio memasuki fase gastrula berbeda nyata menurut hasil uji lanjut BNT, namun pada perlakuan S1 perkembangan embrio jauh tertinggal dari perlakuan yang lain. Hal ini juga terjadi pada penelitian Wahyuningtias et al.(2015) dimana pada saat embrio memasuki fase gastrula terlihat bahwa suhu kontrol yaitu suhu ruangan $\left(26^{\circ} \mathrm{C}\right)$ menunjukkan keterlambatan dengan rentang waktu yang sangat jauh dibanding pada perlakuan suhu yang lain, hal ini disebabkan oleh suhu ruangan yang tidak sesuai untuk perkembangan embrio ikan dan menyebabkan embrio lambat dalam berkembang.Pada penelitian yang dilaporkan oleh Thépot (2015) terlihat bahwa embrio kakap putih memasuki fase Gastrula pada waktu 3 jam 36 menit, hal ini menunjukkan bahwa embrio kakap putih berkembang lebih lambat dibandingkan hasil penelitian Thépot (2015) terutama pada perlakuan S1 $\left(26^{\circ} \mathrm{C}\right)$.

\subsubsection{Organogenesis}

Berdasarkan hasil uji lanjut BNT dengan tingkat kepercayaan $95 \%$ fase organogenesis dapat dilihat dari keempat perlakuan tersebut berbeda nyata antar setiap perlakuan, dimana embrio tercepat memasuki fase organogenesis yaitu perlakuan S4 (287 menit), diikuti perlakuan S3 (354 menit), perlakuan S2 (414 menit) dan perlakuan paling lama yaitu S1 $(606,5$ menit).Pada fase organogenesis, tampak terlihat pengaruh perbedaan suhu terhadap perkembangan embrio dan seperti fase sebelumnya (gastrula) perkembangan embrio pada perlakuan S1 terlihat sangat lambat dibanding perkembangan embrio pada perlakuan suhu yang lain. Menurut Melianawati et al. (2010)berdasarkan penelitiannya, pola perkembangan pada embrio yang diinkubasi dengan suhu terendah pada fase organogenesis berbeda dengan perlakuan lainnya. Pada suhu yang rendah terjadi keterlambatan pola perkembangan embrio. Kondisi suhu media yang rendah diduga berpengaruh terhadap keterlambatan tersebut sehingga menghambat proses perkembangan embrio telur ikan.

Selanjutnya embrio tampak bergerak, hal ini merupakan sistem kerja secara mekanik oleh embrio yang menandakan bahwa embrio sudah mendekati fase penetasan(Muslim, 2019). Pergerakan ini terlihat secara berurut pada perlakuan S4, S3 dan S2 pada menit ke 586, 644, 713. Sedangkan pada perlakuan S1 hingga beberapa menit kedepan tidak menunjukkan adanya tanda-tanda pergerakan berupa detakan. Pada penelitian yang dilaporkan oleh Thépot (2015) terlihat bahwa embrio kakap putih memasuki fase Organogenesis pada waktu 5 jam 35 menit, hal ini menunjukkan bahwa perlakuan $\mathrm{S} 4$ lebih cepat dibanding hasil penelitian Thépot (2015), namun pelakuan S2 dan S3 mengalami keterlambatan serta perlakuan S1 mengalami keterlambatan yang sangat jauh.

\subsubsection{Penetasan}

Berdasarkan uji lanjut BNT 95\% pada fase penetasan, menunjukkan bahwa pengaruh suhu terhadap kecepatan penetasan telur kakap putih berbeda nyata antar setiap perlakuan. Pada fase penetasan terlihat bahwa telur pada perlakuan S4 dengan suhu $32^{\circ} \mathrm{C}$ menunjukkan penetasan tercepat yaitu dengan rata-rata kecepatan 656,5 menit yang diikuti oleh perlakuan $\mathrm{S} 3$ dengan suhu $30^{\circ} \mathrm{C}$ dengan kecepatan menetas yaitu 876 menit, kemudian perlakuan S2 yaitu suhu $28^{\circ} \mathrm{C}$ menunjukkan kecepatan rata-rata penetasan telur yaitu 837,5 menit dan yang terakhir yaitu pada perlakuan S1 selama 2040 menit. Hal ini menunjukkan bahwa terdapat telur yang masih mampu bertahan hidup walau perkembangannya begitu lambat, dimana sesuai dengan pernyataan Pratama et al. (2018) yaitu suhu terlama bagi telur untuk menetas adalah suhu terendah dan suhu tercepat bagi telur untuk menetas adalah suhu tertinggi yaitu $32^{\circ} \mathrm{C}$. Yamagami (1988) dalamNawir et al. (2016) peningkatan suhu dapat berpengruh terhadap sekresi enzim penetasan pada telur ikan, ketika enzim penetasan disekresikan maka pengikisan/penipisan dinding chorion akan lebih cepat pada suhu tinggi dibandikan pada suhu rendah oleh sebab itu proses penetasan pada suhu yang lebih tinggi akan lebih cepat pula. Pada saat itulah pergerakan embrio akan semakin aktif dari sebelumnya bersamaan dengan gerakan tersebut diikuti oleh perputaran dan pergerakan tubuh dalam cangkang hingga terjadinya proses pemecahan cangkang telur dan terlahirlah larva baru. Pada penelitian yang dilaporkan oleh Thépot (2015) terlihat bahwa kakap putih memasuki fase Penetasan pada waktu 11jam 15 menit, hal ini menunjukkan bahwa penetasan pada perlakuan S4 lebih cepat dibandingkan hasil penelitian Thépot, namun perlakuan S2 dan S3 mengalami keterlambatan serta pelakuan S1 yang sangat jauh tertinggal.

Larva kakap putih (Lates calcarifer) strain Asia yang baru saja menetas memiliki panjang antara 4,6 - 6,2 mm dengan tubuh tampak sedikit melengkung ke bawah. Berbeda halnya dengan larva kakap putih strain Australia dalam laporan Thépot and Jerry (2015) dimana panjang total larva yang baru menetas adalah $1.583 \pm 55 \mu \mathrm{m}$ atau setara dengan $1,583 \mathrm{~mm}$. Dimana dapat disimpulkan bahwa walaupun sesama ikan kakap putih, namun apabila berbeda strain atau tempat asal ikan menunjukkan ukuran telur serta larva yang berbeda pula. Hal ini sesuai dengan pernyataan Prihatiningsih (2018) dimana kematangan gonad yang berhubungan dengan fekunditas, ukuran telur dan larva setiap spesies tidak sama, bahkan dengan ikan yang spesiesnya sama. Hal ini disebabkan oleh kualitas telur, makanan serta lingkungannya.

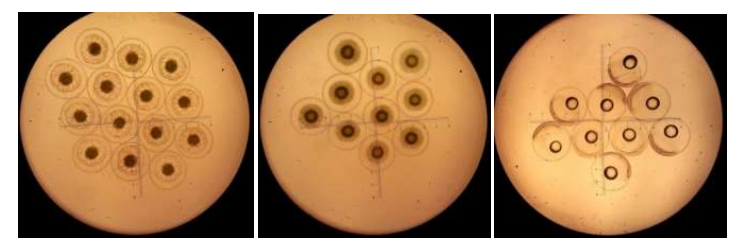

(a)

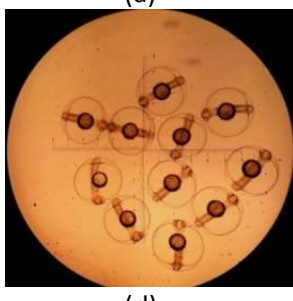

(d) (b)

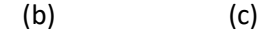

(c)
Gambar 1. Perkembangan Embrio ikan Kakap Purih: (a)Morula, $\begin{array}{lll}\text { (b)Blastula, (c)Gastrula, (d)Organogenesis, } & \end{array}$ (e)Organogenesis

\subsection{Hatching Rate}

Apabila suhu semakin tinggi maka akan menyebabkan persentase penetasan telur (hatching rate) semakin rendah. Namun apabila pada suhu yang dianggap sangat ekstrim 
seperti terlalu dingin (S1) atau terlalu panas (S4) dapat menekan persentase penetasan telur yang menyebabkan telur semakin banyak mengalami kematian baik dalam proses perkembangan embrionya maupun ketika terjai penetasan.

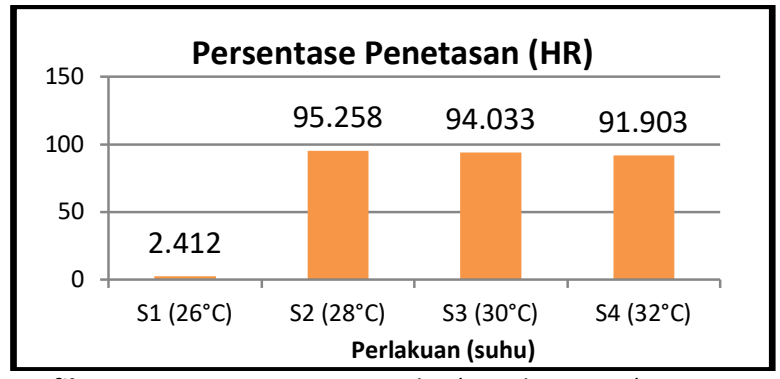

Grafik 1. Persentase Penetasan Telur (Hatching Rate)

Dari Grafik 1 dapat dilihat bahwa derajat penetasan (hatching rate) tertinggi terdapat pada perlakuan S2 dengan suhu $28^{\circ} \mathrm{C}$ yaitu sebesar $95,258 \%$ dan persentase terendah yaitu pada perlakuan S1 dengan suhu $26^{\circ} \mathrm{C}$ sebesar $2,412 \%$.Suhu ektrim dapat menyebabkan derajat penetasan yang semakin rendah hal inikarena suhu yang dapat mempengaruhi proses pembelahan sel pada saat mitosis yang dapat mengakibatkan kerusakan benang-benang spindel yang terbentuk pada saat proses pembelahan sel sehingga terdapat banyak kerusakan pada sel yang mengakibatkan menurunnya derajat penetasan (Hijriyati, 2012). Dalam penelitian yang dilaporkan oleh Thépot (2015) terlihat bahwa suhu $28^{\circ} \mathrm{C}$ memiliki persentase penetasan yaitu $52,3 \%, 30^{\circ} \mathrm{C}$ memiliki persentase penetasan $86,6 \%, 32^{\circ} \mathrm{C}$ memiliki persentase penetasan $76,3 \%$. Hal ini menunjukkan bahwa persentase penetasan dalam penelitian ini lebih tinggi dibandingkan dengan persentase penetasan dalam penelitian Thépot (2015), sedangkan perlakuan dengan suhu $26^{\circ} \mathrm{C}$ dalam penelitian Thépot (2015) mengalami kematian secara keseluruhan namun dalam penelitian ini terdapat beberapa telur yang mampu menetas walau sangat lambat.

\subsection{Abnormalitas Larvalkan Kakap Putih}

Menurut Dewanti et al. (2014) telur yang telah terbuahi dapat gagal untuk menetas karena sel sperma yang abnormal dan kondisi yang tidak memungkinkan untuk perkembangan embrio (faktor lingkungan) seperti suhu yang tidak sesuai.

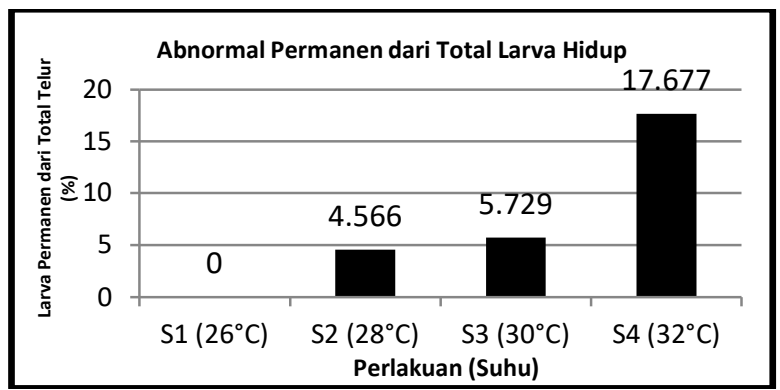

Grafik 2. Jumlah Abnormal Permanen dari Total Larva Hidup

Pada Grafik 2 terlihat bahwa perlakuan S4 miliki nilai persentase abnormalitas yang sangat tinggi dibanding perlakuan lainnya yaitu sebesar $17,677 \%$ dari total keseluruhan telur dalam wadah perlakuan S4 sedangkan pada perlakuan S1 sebanyak $0 \%$.Sehingga dapat disimpulkan bahwa pengaruh perbedaan suhu terhadap abnormalitas larva ikan kakap putih
(Lates calcarifer) memiliki persentase yang lebih rendah pada suhu yang lebih rendah.Menurut Aslianti et al. (2014)tulang belakang yang abnormal akan berdampak pada kelangsungan hidup larva sehingga larva tumbuh lambat atau kerdil dan memungkinkan larva akan cepat mati.Apabila faktor internal seperti kualitas sperma yang kurang baik dan kemudian didukung dengan faktor lingkungan seperti suhu yang juga kurang baik pula maka akan semakin memperburuk keadaan dari embrio yang akan menetas.

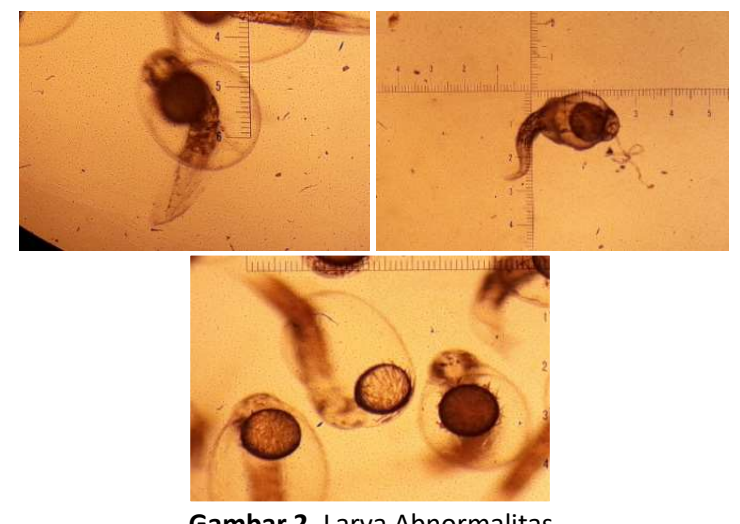

\subsection{Kualitas Air}

Parameter kualitas air yang perlu diukur dan penting bagi kelangsungan hidup telur hingga menjadi larva dalam penelitian ini yaitu $\mathrm{pH}$, Oksigen Terlarut (DO) serta Salinitas. Parameter tersebut harus tetap berada pada batas normal.

Tabel 2. Kondisi Kualitas Air Pada Saat Penelitian

\begin{tabular}{ll}
\hline Parameter & Hasil Uji \\
\hline Salinitas & $31 \mathrm{ppt}$ \\
Derajat Keasaman (pH) & $8,6-8,8$ \\
Oksigen Terlarut (DO) & $4,04-4,32 \mathrm{mg} / \mathrm{L}$ \\
\hline
\end{tabular}

Selama penelitian berlangsung kondisi kualitas air pada setiap wadah tetap stabil dan sesuai dengan standar (batas normal), parameter berupa salinitas air berada pada batas normal yaitu 31ppt, derajat keasaman $(\mathrm{pH})$ media air berada pada kisaran 8,6 - 8,8 yang merupakan batas normal untuk pemeliharaan telur dan larva ikan kakap putih. Violita et al. (2019) mengatakan bahwa pH yang rendah dapat menyebabkan kerja enzim chorionase menjadi terganggu, sebab enzim ini tidak dapat bekerja secara optimum pada $\mathrm{pH}$ yang lebih asam atau rendah. Oksigen terlarut berada pada kisaran 4,04 - 4,32 yang merupakan kisaran oksigen terlarut yang dapat mendukung perkembangan embrio, sedangkan perlakuan berupa suhu pada wadah dicek setiap satu sampai dua jam sekali yang terbukti tetap stabil.

\section{Kesimpulan}

Berdasarkan penelitian yang telah dilakukan dapat kesimpulan bahwa perbedaan suhu memberikan pengaruh yang sangat nyata terhadap perkembangan embrio, kecepatan penetasan telur, derajat penetasan serta abnormalitas larva ikan kakap putih (Lates calcarifer). Serta suhu yang dianggap baik bagi perkembangan telur, derajat penetasan serta abnormalitas larva ikan kakap putih yaitu pada suhu $28^{\circ} \mathrm{C}$. 


\section{Bibliografi}

Aidil, D., Zulfahmi, I. and Muliari. 2016. Pengaruh Suhu Terhadap Derajat Penetasan Telur dan Perkembangan Larva Ikan Lele Sangkuriang (Clarias gariepinus var. sangkuriang). JESBIO, V: 30-33.

Andriyanto, W., Slamet, B. and Ariawan, I.M.D.J. 2013. Perkembangan Embrio dan Rasio Penetasan Telur Ikan Kerapu Raja Sunu (Plectropoma laevis) Pada Suhu Media Berbeda. J. IImu dan Teknol. Kelaut. Trop., 5: 192-203.

Aslianti, T., Nasukha, A. and Setyadi, I. 2014. Perkembangan Tulang Belakang dan Aktivitas Enzim Protease Larva Ikan Bandeng, Chanos chanos Forsskal yang Dipelihara Pada Media Berbeda. J. Ilmu dan Teknol. Kelaut. Trop. 6: 87-100.

Dewanti, R., Yuhan and Sudiyono. 2014. Pengaruh Bobot Dan Frekuensi Pemutaran Telur Terhadap Fertilitas, Daya Tetas, Dan Bobot Tetas Itik Lokal. Bul. Peternak., 38: 16-20.

Farida, Rachimi and Adrianus. 2016. Pengaruh Suhu Yang Berbeda Terhadap Waktu Penetasan Dan Kelangsungan Hidup Larva Ikan Biawan (Helostoma temmincki). 4: 63-69.

Hijriyati, K.H. 2012. Kualitas Telur Dan Perkembangan Awal Larva Ikan Kerapu Bebek [Cromileptes altivelis, Valenciennes (1928)] di Desa Air Saga, Tanjung Pandan, Belitung. Universitas Indonesia.

Melianawati, R., Lmanto, P.T. and Made Suastika, A.P. 2010. Perkembangan Embrio dan Penetasan Telur Ikan Kerapu Lumpur (Epinephelus coioides) Dengan Suhu Inkubasi Berbeda. Jumal Penelit. Peikanan Indonesia, 8: 7-14.
Muslim, M. 2019. Teknologi Pembenihan Ikan Betok (Anabas testudineus). Bandung: PT. Panca Terra Firma.

Nawir, M., Sukendi and Nuraini. 2016. The Embryonic Of Pawas (Osteochilus hasselti C.V) With Different Temperature. J. Online Mhs. Fak. Perikan. dan IImu Kelaut. Univ. Riau (JOM FAPERIKA UNRI), 3: 1-11.

Pratama, B.A., Susilowati, T. and Yuniarti, T. 2018. Pengaruh Perbedaan Suhu Terhadap Lama Penetasan Telur, Daya Teteas Telur, Kelulushidupan dan Pertumbuhan Benih Ikan Gurame (Osphronemus gouramy) Strain Bastar. J. Sains Akuakultur Trop., 2: 59-65.

Prihatiningsih, Edrus, I.N., and Sumiono, B. 2018. Biologi Reproduksi, Pertumbuhan dan Mortalitas Ikan Ekor Kuning (Caesio Cuning Bloch, 1791) Di Perairan Natuna. BAWAL WIDYARISET PERIKANAN TANGKAP, 10: 1-15.

Redha, A.R., Raharjo, E.I. and Hasan, H. 2014. Pengaruh Suhu Yang Berbeda Terhadap Perkembangan Embrio dan Daya Tetas Telur Ikan Kelabau (Osteochilus melanopleura). J. RUAYA, 4: 1-8.

Thépot, V. and Jerry, D.R. 2015. The effect of temperature on the embryonic development of barramundi, the Australian strain of Lates calcarifer (Bloch) using current hatchery practices. Aquac. Reports, 2: 132138. Elsevier B.V.

Violita, V., Muslim, M. and Fitrani, M. 2019. Derajat Penetasan dan Lama Waktu Menetas Embrio Ikan Betok (Anabas testudineus) yang Diinkubasi pada Media dengan $\mathrm{pH}$ Berbeda. JIPK J. IIm. Perikan. Dan Kelaut., 11: 21-27.

Wahyuningtias, I., Diantar, R. and Arifin, O.Z. 2015. Pengaruh Suhu Terhadap Perkembangan Telur dan Larva Ikan Tambakan (Helostoma temminckii). e-Jurnal Rekayasa dan Teknol. Budid. Perair., IV: 439-448. 